\title{
Transformed Precedent Phrases in the Headlines of Online Media Texts as Paratexts
}

\begin{abstract}
By Darya A. Mironova*
Precedent phrases represent the utterances that are characterized by recognizability, reproducibility, as well as by an absolute cultural value for a certain linguocultural community. The research is focused on the precedent phrases, the semantics and/or the structure of which have been intentionally transformed with the aim to achieve a certain communicative effect. When being used in the headlines of online media texts, transformed precedent phrases manifest their threefold nature: they function as 1) "expressemes", 2) symbols of precedent phenomena, and 3) paratexts. The paper studies transformed precedent phrases in the headlines of American and British online media texts with the aim of exploring their peculiarities as paratexts.
\end{abstract}

Keywords: Precedent phrases, Transformed precedent phrases, Paratext, paratextual connections, Online media texts.

\section{Introduction}

Anthropocentric paradigm of modern academic studies gives rise to the scholarly interest in such phenomena as: dialogueness of text, intertextual references, reproducibility of culturally loaded linguistic units, etc. Special attention is paid to precedent phenomena, i.e. core elements included in a cognitive base of a certain linguocultural community. Precedency is an inherent feature of those texts that are highly valued, well-known and widely used both by a certain linguistic personality, and by language groups (Karaulov 1987).

Precedent phenomena (texts, situations, names and phrases) are characterized by recognizability, reproducibility, as well as by an absolute cultural value (Karaulov 1987). This phenomenon has been the object of study by a range of Russian scholars (Gudkov 2003, Krasnykh 2003, Prokhorov 2004, Zakharenko 1997, Zakharenko et al. 1997). Precedent phrases (PPs), which represent the focus of our study, are defined as reproducible products of speech and mind activity, complete and all-sufficient units, which can be either predicative or nonpredicative; complex signs, the general meaning of which is not equal to the meanings of its components put together (Zakharenko et al. 1997: 83).

Precedent phrases include proverbs, sayings, "winged words", quotes, aphorisms, slogans, mottos, titles of literature works, songs, films, etc. However, the paper covers only two groups of transformed precedent phrases - quotes and titles.

According to I.V. Zakharenko, PPs can be divided into two groups: (a) non-transformed phrases (used in their initial, intact form) and (b) transformed phrases (Zakharenko 1997). The second group represents the object of our

${ }^{*}$ Associate Professor, Chelyabinsk State University, Russia. 
research. Transformation of PPs implies the intentional change with the purpose of achieving a desired communicative effect.

As to the types of transformation, we use classification suggested by A.M. Melerovich and V.M. Mokienko, according to which transformation that entails a change in the meaning of a source PP and the preservation of the overall initial structure is referred to as semantic, whereas transformation that consists in a change of both the meaning and the initial structure of a PP is described as structural-semantic (Melerovich and Mokienko 2001). E.g.:

1) semantic transformation: Georgia on Their Minds [Russia's war against Tbilisi didn't start with invasion] (The Wall Street Journal; Oct 1, 2009) $\leftarrow$ PP: Georgia on My Mind (source precedent text: the official state song of the State of Georgia, USA);

2) structural-semantic transformation: Mr. Publisher, Don't Tear Down That Wall (The Huffington Post; Jul 10, 2010; M. Sigman) $\leftarrow$ PP: $\underline{\underline{M r}}$. Gorbachev, tear down this wall! (source precedent situation: the challenge issued by the United States President R. Reagan to Soviet Union leader M. Gorbachev to destroy the Berlin Wall).

Transformed precedent phrases (TPPs) are popular in the mass media; journalists include them in the headlines to catch the readers' attention. The destruction of a pattern (either on structural or solely on semantic level) is meant to change the recipients' perception of a linguistic unit, and impress them by "deceiving" their expectations. By alluding to familiar expressions, authors try to bond with the audience. The impact is intensified when PPs are transformed, since they contain the encoded message, the meaning of which cannot be derived simply from the linear, or the horizontal context (a sentence or a passage of a media text, i.e. narrow context, or a whole media text, i.e. broad context). Interpolation of TPPs into a headline contributes to its intricacy, therefore the more inventive a journalist is, the brighter is his material and its impact on the readers.

Our observations show the lack of research on the precedent phrases as the objects of translation, whereas an increased interest in the translation of online media texts from the English language requires comprehensive study of TPPs in the headlines.

When being used in the headlines of online media texts, transformed precedent phrases (TPPs) manifest their threefold nature. Firstly, a precedent phrase transformed by an author of a media text acts as a word play technique. Its expressive properties allow us to attribute it to expressemes (term by V.G. Kostomarov 1971). Secondly, the perception of TPPs reveals the associations with a precedent text or a precedent situation, which an author of a media text refers to, therefore a transformed precedent phrase acts as the symbol of a precedent phenomenon. Thirdly, being a part of a headline of an online media text, a TPP functions as a paratext, a notion that encompasses a range of heterogeneous, liminal elements (either verbal or non-verbal) that enframe the main text. 
In keeping with the threefold nature of TPPs in the headlines of online media texts, we distinguish three groups of parameters that influence the strategy of their translation: a) expressive and structural-semantic parameters; b) linguocultural parameters; c) paratextual parameters.

The paper studies transformed precedent phrases in the headlines of American and British online media texts with the aim of exploring their paratextual peculiarities.

Research questions include the following:

a) How does the online environment influence the paratextual peculiarities of TPPs interpolated in the headlines of online media texts?

b) How can various types of paratextual connections between a media text and a source precedent phenomenon be categorized?

c) How can various modes of reference to the source phenomena be categorized?

d) How can paratextual parameters of TPPs potentially influence the process of their translation into another language?

\section{Materials and Methods}

Our study is focused on transformed precedent phrases (TPPs), functioning in the headlines of online media texts. Our observations are based on the analysis of more than 640 media texts from 23 American and British online media resources (the Independent, the Guardian, the London Evening Standard, the Daily Mail, the Wall Street Journal, the Washington Post, the New York Post, etc.).

The analysis was not limited to the headlines or specific linguistic units; it also involved the study of both the horizontal and the vertical context (Akhmanova and Gyubbenet 1997). The latter includes background information about source precedent phrases, source texts, etc.

By decoding subsurface linguistic and extralinguistic information, which is not expressed explicitly, we aimed at studying: a) the types of connection to the source precedent phenomenon of a headline and a media text; b) the ways in which such connections are manifested.

\section{Transformed Precedent Phrases as Paratexts}

Headlines can be defined as paratexts - the notion introduced by G. Genette. Paratextuality, according to G. Genette, is one of the categories of transtextuality ("textual transcendence of the text") alongside with intertextuality, architextuality, metatextuality, and hypertextuality (Genette 1997a). Paratexts encompass a range of heterogeneous, liminal elements (either verbal or non-verbal) that enframe the main text: titles, forewords, prefaces, abstracts, epigraphs, footnotes, illustrations, etc. These elements represent a threshold, or, in the words of Ph. Lejeune, "a 
fringe of the printed text which in reality controls one's whole reading of the text" (Genette 1997b: 2). According to G. Genette, "these productions ... surround it [a text] and extend it, precisely in order to present it, in the usual sense of this verb but also in the strongest sense: to make present, to ensure the text's presence in the world ..." (Genette 1997b: 1).

In the online environment, the functions of TPPs, performing as a paratext (or its component), are expanded, and traditional "paratext - text" correlation model is morphed. Headlines, together with subheads, leads and other elements, can form paratextual groups that function as the autonomous information molecules on the starting page of a site. These groups can be defined as microtexts that can give a hint about the content of macrotexts (the main body of a media text).

The target audience of a particular media resource can find out about the current news by quickly scanning the headlines without clicking on a hyperlink leading to a full article. In these cases, paratextual groups do not usher readers into a macrotext, or they do so only potentially. Thus, in the autonomous mode, headlines function as paratexts that belong to their microtexts (subheads, leads, etc.), and in a broader sense - as paratexts related to a range of all neighboring microtexts presented on an online page.

When readers click on a hyperlink to read the full text of an article, a microtext and its headline start to function as one paratextual group that belongs to a macrotext.

Moreover, headlines can function as hyperlinks adjacent to a different macrotext on a similar topic.

To sum up, headlines in online media texts function in the following modes:

a) as a paratext to a microtext 1 (when adjacent to subheads, leads and not a full media text);

b) as a paratext to a macrotext 1 (when adjacent to a full media text);

c) as a paratext to a macrotext 2 (as a hyperlink adjacent to a different text on a similar topic);

d) as a paratext to a microtext 2, 3, $4 \ldots$ (as one of many elements of an online page).

This paper is limited to exploring only the paratextual relations of the modes a) and b).

\section{Types of Paratextual Connections}

TPPs interpolated into the headlines form the following chain of links: "source precedent text/source precedent situation - source precedent phrase transformed precedent phrase as a part of paratext - microtext / macrotext".

Our observations show that the connection between the first and the last links differs considerably, depending on whether it is conditioned by the minor, incidental factors or by the deeper, more valid ones. Based on such criteria we 
distinguish the following types of paratextual connections: surface, indirect, direct, and deep.

Surface connection presupposes the absence of any reference to the essence of a source text. The use of a certain PP as the basis for transformation is conditioned by the match of superficial, linear meaning of the phrase to the subject matter of the article. The following headlines that contain a transformed title of a famous novel by $\mathrm{Ch}$. Dickens A Tale of Two Cities illustrate this idea.

a) A Tale of Three Cities (The Wall Street Journal; May 3, 2010; B.M. Carney).

b) A Tale of China's Two Great Cities (The Los Angeles Times; Oct 4, 2010; B. Demick).

c) A Tale of Two Political Generations (USA Today; Feb 24, 2011; C. Raasch).

None of these articles touch upon the novel, its plot, characters, leitmotif, etc. The only common point is the presence of two or more objects of narration (whether cities or not).

Another productive precedent source of transformation - a quote from Hamlet by W. Shakespeare: to be or not to be - that is the question. The motivation of reference is reduced to the presence of a dilemma in the narration of both the article and the source text (which, however, has a completely different nature: the idea of quest for the essence of life is in most cases materialized and downgraded when the phrase undergoes transformation). Apart from it, the author's choice is stimulated by a graphic and/or phonetic similarity of the constituent elements:

a) Travel Insurance: to Buy or not to Buy? (USA Today; Jun 18, 2010; J. Berman).

b) TB or not TB, that is the Question ... (The Telegraph; Nov 13, 2010; J. McCartney).

c) To Believe or not to Believe? (The Wall Street Journal; Jan 28, 2011; Mr. T. Teachout).

The authors use the recognizable structure as the means of contributing to the aesthetics of the headline, demonstrating their intertextual competence and the intention to dialogize the media text. By means of altering a fixed pattern, authors strive for novelty and originality to capture readers' attention.

The choice to include a TPP into a headline can also be caused by such extraneous factors as the popularity of a source material at the moment of the media text creation. E.g.:

a) Eat, pray - and vote (The Washington Post; Sep 21, 2010; K.V. Heuvel).

The TPP represents a transformed title of a drama film Eat Pray Love, which is based on E. Gilbert's 2006 best-selling memoir of the same name that 
chronicles the author's trip around the world after her divorce. However, the topic of the media text is not related to the film itself, but is devoted to the US Senate elections and the disappointment among voters. The author encourages readers to channel all frustration into making change and to start campaigning for their principles. The movie was released in theaters on August 13, $2010-$ just a month before the publication of the article. This signifies, on the one hand, high precedency of the phrase at the moment and, on the other hand, the author's desire to benefit from it by attracting readers' attention to the politically oriented content.

Indirect connection is the second type of the paratextual connection we distinguish, which presupposes the presence of circumstantial connection between a headline and the source of the TPP. In this case, a journalist chooses a certain precedent phrase because the object of narration is related to the precedent text, which the original phrase is derived from. E.g.:

a) Take a Chance on Greece (The Sun; Jul 12, 2008; N. Parker).

The article tells about the Greek island of Skopelos, which became the filming spot for Mamma Mia! - 2008 musical/romantic comedy film. The movie is adapted from the 1999 West End/2001 Broadway musical of the same title, based on the songs of successful Swedish pop group ABBA. The headline contains the transform of the title of one of the group's hits - Take a Chance on $m e$ (1978), also featured in the film.

The choice of the PP for the following headline is also explained by the indirect relation between the content of the article and the source:

a) City Woman (The New York Post; Oct 10, 2010; J.G. Keil).

The headline represents the transform of the title of 1990 romantic comedy film that features R. Gere and J. Roberts - Pretty Woman. The intent of the leading actress of the movie to buy new urban real estate is the topic of the article.

Direct connection relates to the situation when a source precedent text represents the object of narration of the media text. E.g.:

Another example when the use of the transform implemented by the author is explained by the title of the source being the topic of the article is the following:

a) Britain's got no Talent Spotters (The Daily Star; May 31, 2009; G. Bushell).

In the headline, the author mocks the title of the popular British television talent show Britain's Got Talent. The sarcastic tone is preserved through the whole media text which criticizes the system of judging the contestants of the show.

The final type that we distinguish is deep connection. In this case, the author is guided by the fact that the source and the article, the headline of which contains the TPP, share something common in their background. The background of such nature usually involves facts concerning the source's plot, 
leitmotif or theme. These additional shades of meaning and extra semantic dimension may, however, fail to be decoded by readers who do not possess similar knowledge, unless the motivation is explained by the journalist, which he may avoid to do relying on the readers' intertextual competence. In the following example, the author wittily hints at the common points that the topic of the article and the plot of the source text share:

a) The Spy Who Loves Media (The Guardian; Oct 12, 2009; I. Cobain).

The headline represents a transformed title of the tenth film in the J. Bond series based on one of I. Fleming's novels about a British MI6 agent - The Spy Who Loved Me (1977). The storyline involves a reclusive megalomaniac named Stromberg who plans to destroy the world and create a new civilization under the sea. Bond who teams up with a rival Soviet KGB agent A. Amasova strives to stop Stromberg. The media text, that follows the life cycle of A. Lebedev, Russian billionaire businessman, was written in response to the news that he became the owner of the London Evening Standard newspaper. The story is spiced up by the fact that Mr Lebedev is a former KGB agent (like Ms Amasova) who used to work undercover in London. His latest business move gave rise to the criticism and was interpreted by many as an attempt to control the Western media in order to project a better image of Russia. Thus, the headline sarcastically hints at factual similarities that the object of narration and the storyline of the source share. These are, namely, the issues of close contact and yet antagonistic, rival relations between the Soviet/Russian intelligence service and Great Britain. Next headline refers to the leitmotif of the source text:

\section{a) Poland's Choice (The Financial Times; Jun 22, 2010; Editorial).}

The source precedent phrase and at the same time the title of the source precedent text is Sophie's Choice, the 1982 American romantic drama film directed by A.J. Pakula and the 1979 a novel by W. Styron. The plot tells a tragic story of a Polish immigrant, S. Zawistowski. When she became a prisoner in the Auschwitz concentration camp, Sophie was forced to choose which one of her two children would be gassed and which would proceed to the labor camp. To avoid having both children killed, she chose Jan, her son, to be sent to the children's camp, and her daughter Eva to be sent to her death in crematorium.

The author draws a parallel between the novel's/movie's circumstances and the ones that Poland found itself in. The media text is devoted to the elections in Poland, the people of which after tragically losing their president L. Kaczyński in the plane crash near Smolensk (Russia), had to make a crucial choice between two major candidates - J. Kaczyński, the identical twin brother of the deceased president, and the acting president B. Komorowski. However, the country seems lost and reluctant since none of them received the majority of votes in the first round. Thus, by alluding to this story, the journalist refers to a common leitmotif of an unbearably painful decision that has to be made against the backdrop of tragic circumstances when a person is put under the pressure to make a lifechanging choice to avoid even graver repercussions. 


\section{Modes of Reference to the Source}

The mode of reference to a source text usually falls into either of these two categories: verbalized and not verbalized.

Our analysis shows that the majority of the journalists do not verbalize the source of the interpolated TPPs, which can be explained by the presumption that the intertextual competence of the readers will make it possible to decode the author's allusions, hints and intentions. Moreover, according to our observations, the reference is usually not verbalized when the connection to the precedent phrase has a surface character.

In case the author decides to make the paratextual connections transparent, he chooses the following ways to verbalize them:

\section{Interpolation of a source text title into a paratext.}

- E.g.: May the Fourth be with You: Sci-Fi Film Fanatics Tie the Knot in Star Wars Themed Ceremony (The Daily Mail; May 5, 2009; E. Andrews).

The source precedent phrase May the Force be with you has achieved cult status and is symbolic of the Star Wars legacy. The line has been said by at least one character in each of the Star Wars movies. The media text tells about the sci-fi movie fans who celebrated their theme wedding on May the $4^{\text {th }}$, the day considered to be the official holiday by the fans of Star Wars culture, which explains the author's pun upon the phrase. Other examples:

- Jingle bells? It's Jingle Hell - and We Women have ourselves to Blame (The Daily Mail; Jun 5, 2010; D. Kelly).

- Eat Pray Love? More like "Me Me Me" amid Beautiful Scenery (USA Today; Aug 14, 2010; C. Puig).

\section{Interpolation of allusions related to a source into a paratext.}

- E.g.: Arnold Schwarzenegger: I'll be Back on the Big Screen (The Guardian; Jan 17, 2011; B. Guild).

I'll be back is a catchphrase associated with A. Schwarzenegger, who first used it in 1984 science fiction thriller film The Terminator. The media text tells about the plans of the ex-governor of California to continue his acting career.

- E.g.: Frankly, She doesn't Give a Damn: Clark Gable's Bleary-Eyed Granddaughter Falls down in the Street (The Daily Mail; Oct 9, 2008; E. Sheridan).

The headline of the media text condemning inappropriate behavior of the granddaughter of the famous actor $\mathrm{C}$. Gable includes the transform of the 
following expression: Frankly, my dear, I don't give a damn. It is a catchphrase from 1939 film Gone with the Wind starring V. Leigh and C. Gable, whose character, R. Butler, says these last words to S. O'Hara before he leaves her.

\section{Interpolation of the title of a source text into a macrotext.}

- E.g.: No Longer a Phantom of Pop Opera (The Telegraph; Mar 11, 2010; C. Spencer).

The choice of the precedent phrase, which the headline is based on, can be explained by the narration of the article that tells about the premiere of a new musical Love Never Dies by A.L. Webber. The author gives further details in the macrotext: The reviews for his latest show, Love Never Dies, a sequel to his biggest and most enduring hit, The Phantom of the Opera, ranged from a fivestar rave in The Independent to a miserly, nit-picking two stars in The Times.

- E.g.: UFOs: the (boring) truth is out there (The Guardian; Feb 18, 2010; N. Pope).

The headline is a transform of the precedent phrase The truth is out there, a popular tagline of the television science fiction series The X-files (19932002), the main characters of which investigate cases that involve supernatural activity and search the evidence of the intelligent extraterrestrial life existence. The journalist writes about the released Ministry of Defense UFO files that failed to impress him since they did not contain any valid proof of UFOs existence. The author wonders: The newly released files cover the period 1994 to 2000. It's interesting to note that the cult TV series The X-Files was at the height of its popularity at this time. Might this have influenced people making UFO reports? ...

\section{Interpolation of several precedent phrases from one source into both a paratext and a macrotext.}

- E.g.: To Raise or not to Raise Capital (The Financial Times; Dec 1, 2008; L. Saigol).

The headline is based on the opening phrase of Hamlet's soliloquy To be or not to be (Act 3, Scene 1) in W. Shakespeare's play The Tragedy of Hamlet, Prince of Denmark. The author, however, goes beyond using a TPP only in the headline. The media text, which narrates about the way Deutsche Bank deals with the losses caused by credit crisis, starts with the following sentence:

- Something is rotten in the state of Hesse.

This is the reference to the German state where the headquarters of the bank are located. The transform is based on the famous phrase Something is 
rotten in the state of Denmark (Hamlet; Act 1, Scene 4), spoken by Marcellus about the fact that the country was festering with moral and political corruption. The text also ends with the transformed quote from Hamlet, thus creating a circular structure of the intertextual elements. The author finishes the articles with the following words:

- Alas, poor Josef, they knew his ratio.

The author refers to the bank's chief executive J. Ackermann and wistfully points out the faultiness of the decisions he took. The source precedent phrase - Alas, poor Yorick! I knew him, Horatio (Hamlet; Act 5, Scene 1) - was said by the grieving Prince as he looked at the skull of Yorick, a court jester he had known as a child. The examples above show that the parallel between the bank's financial turmoil and the classic tragedy is evident throughout the whole text. Let us provide another example of this type of verbalization:

- Gimme Gimme Gimme ... a Meal after 10 am (The Independent; Aug 1, 2009; S. Calder).

This headline consists of the TPP based on the title of a hit song by ABBA Gimme! Gimme! Gimme! (A Man after Midnight). However, not only the headline but the whole article is interspersed with transformed quotes from the songs by this Swedish pop group. The author covers the news about the lossmaking carrier British Airways that scrapped meals on short-haul flights; as a result, the passengers on flights lasting less than two and a half hours will not receive a meal after $10 \mathrm{am}$. This move urged a lot of passengers to avoid flying this airline - the effect labelled as ABBA = "Anybody But British Airways".

Because of the phonetic and graphic equivalence of the abbreviation to the name of the pop group, the author playfully includes references to the source throughout the whole macrotext. Here are the examples:

- Can you hear the drums? ... the airline's misfortunes are chiming with the songbook of Sweden's only supergroup; Anybody But British Airways - the slogan for people who are worried that, should a strike begin, they couldn't escape if they wanted to (quote from 1974 single "Waterloo").

- Don't be afraid to ask for another; in the past, I have. If I had to do the same again I would, my friend (both are quotes from 1975 song "Fernando").

- Money, money, money ... lies at the heart of no-meals-on-wheels move (the title and the quote from 1976 song);

- The name of the game in the longer term? (the title of 1977 song).

The authors that choose this mode of the connection between a transformed precedent phrase as a headline and a source text, demonstrate a high level of creativity. 
In some cases, journalists make reference to a source by incorporating visual elements. For example, in the following headline the author transforms the quote and the title of E. John's song Sorry seems to be the hardest word:

- Sorry Seems to be the Easiest Word for Over-Apologetic Brits (The Mirror; Sep 13, 2011; L. Hanna).

No mentioning of the source is included in the text, which is devoted to the British national habit of constantly apologizing. However, the media text is accompanied by the image of Sir E. John, which drops a hint to the readers and helps them decode the reference. The same approach is used in the following article:

- All the Single, Higher Earning Ladies (The Wall Street Journal; Sep 1, 2010; R.E. Silverman).

All the single ladies is a quote from the popular song Single Ladies by Beyonce. The absence of verbalized reference to the source is offset by the presence of the image from the Single Ladies music video in the article. The author uses the precedent phrase from the song that is perceived by many as an anthem of all independent, confident women in relation to the article, which tells about an increasing number of young females who earn more than their male counterparts, which makes this reference especially pertinent.

\section{Discussion}

The paratextual parameters categorized and described in this paper play a crucial role in determining tactics and operations chosen by translators.

During the processes of identifying and decoding transformed precedent phrases in online media headlines, surface paratextual connections presumably represent the most difficulty, since there are no indicators of the substantial relation between a precedent phenomenon and a microtext/a microtext. In this case, translators are expected to be knowledgeable enough to discover hidden signs that highlight the presence of distorted patterns. If they fail to establish the connection between a phrase and the underlying context, the author's intention (e.g. sarcastic, ironic implications) will not be fully deciphered.

In the cases of indirect, direct and deep connections, such indicators are present in either explicit or implicit forms. At the stage of target text production, the indirect type of connection provides more freedom for translation transformations. In the cases of indirect, direct and deep types of connection between a source and the content of the article, the choice of equivalents is limited. However, translators may refuse to manifest the connection between precedent phenomena and a media text if there are limitations put by other parameters.

The mode of reference to the source influences the translation process as well. The absence of any signals that show the connection between the content of a media text and a precedent phenomenon, may complicate the process of decoding 
the word play, whereas verbal and non-verbal signals make the process of understanding easier. However, they can put restrictions on potential translation decisions while searching for equivalents if the source precedent phenomena are not considered precedent for the recipient linguocultural community.

Thus, the suggested classifications of paratextual connections, as well as of the modes of reference, provide insight into the peculiarities of transformed precedent phrases used in the headlines of online media texts, which is potentially valuable in translation practices, both for decoding a source message and for producing a new target text.

\section{Acknowledgements}

The study has been carried out with the support of the Russian Humanitarian Scientific Fund (project \#15-04-00455).

\section{References}

Akhmanova OS, Gyubbenet IV (1997) 'Vertikal'nyi kontekst' kak filologicheskaia problema ('Vertical Context' as Philological Problem). Voprosy iazykoznaniia (3): 47-54.

Genette G (1997a) Palimpsests: Literature in the Second Degree. Lincoln and London: University of Nebraska Press, p. 492.

Genette G (1997b) Paratexts: Thresholds of Interpretation. Cambridge University Press, p. 427.

Gudkov DB (2003) Teoriia i praktika mezhkul'turnoi kommunikatsii (Theory and Practice of Intercultural Communication). Moscow: Gnozis, p. 288.

Karaulov YN (1987) Russkii iazyk i iazykovaya lichnost' (The Russian Language and Language Individuality). Moscow: Nauka, p. 264.

Kostomarov VG (1971) Russkiy Yazyk na Gazetnoi Polose (The Russian Language in Newspapers). Moscow: MSU Printing House, p. 268.

Krasnykh VV (2003) Svoi sredi chuzhikh: mif ili real "nost"? ('Friend' among 'foes': myth or reality?). Moscow: Gnozis, p. 375.

Melerovich AM, Mokienko VM (2001) Frazeologizmy v russkoi rechi (Idiomatic Expressions in Russian Speech, Dictionary). Moscow: Russian Dictionaries, Astrel, p. 855.

Prokhorov IE (2004) Deistvitol 'nost'. Tekst. Diskurs (Reality. Text. Discourse). Moscow: Flinta, Nauka, p. 224.

Zakharenko IV (1997) K voprosu o kanone i etalone $\mathrm{v}$ sfere pretsedentnykh fenomenov (On the Issue of Canon and Standard in the Sphere of Precedent Phenomena). Iazyk, soznanie, kommunikatziia (1): 104-114.

Zakharenko IV, Krasnykh VV, Gudkov DB, Bagaeva DV (1997) Pretsedentnoe imia i pretsedentnoe vyskazyvanie kak simvoly pretsedentnykh fenomenov (Precedent Name and Precedent Phrase as Symbols of Precedent Phenomena). Iazyk, soznanie, kommunikatziia (1): 82-103. 


\section{$\underline{\text { Electronic Sources }}$}

The Daily Mail, available at: http://www.dailymail.co.uk.

The Daily Star, available at: http://www.dailystar.co.uk.

The Financial Times, available at: http://www.ft.com.

The Guardian, available at: http://www.guardian.co.uk.

The Huffington Post, available at: http://www.huffingtonpost.com.

The Independent, available at: http://www.independent.co.uk.

The Los Angeles Times, available at: http://www.latimes.com.

The Mirror, available at: http://www.mirror.co.uk.

The New York Post, available at: http://www.nypost.com.

The Sun, available at: http://www.thesun.co.uk.

The Telegraph, available at: http://www.telegraph.co.uk.

The Wall Street Journal, available at: http://online.wsj.com/europe.

The Washington Post, available at: http://www.washingtonpost.com.

USA Today, available at: http://www.usatoday.com. 
